\title{
Species and abundance of ectoparasitic flies (Diptera) in pied flycatcher nests in Fennoscandia
}

\author{
Tapio Eeva ${ }^{1 *}$, Tommi Andersson², Åsa M. M. Berglund ${ }^{3}$, Jon E. Brommer ${ }^{1}$, Raimo Hyvönen ${ }^{4}$, Tero Klemola',
} Toni Laaksonen ${ }^{1}$, Olli Loukola ${ }^{5}$, Chiara Morosinotto ${ }^{1}$, Kalle Rainio ${ }^{1}$, Päivi M. Sirkiä1,6 and Eero J. Vesterinen ${ }^{1,7}$

\begin{abstract}
Background: Birds host several ectoparasitic fly species with negative effects on nestling health and reproductive output, and with the capability of transmitting avian blood parasites. Information on the abundance and distribution of the ectoparasitic fly genera Ornithomya (Hippoboscidae) and Protocalliphora (Calliphoridae) in northern Europe is still generally poor, and we thus explored their geographic range and occurrence of these flies in the nests of a common avian model species, the pied flycatcher Ficedula hypoleuca.

Methods: Nests of F. hypoleuca were collected from 21 locations across Fennoscandia in summer 2013, across a latitudinal gradient (between $56^{\circ} \mathrm{N}-70{ }^{\circ} \mathrm{N}$ ) and examined for the presence of fly puparia. Adult specimens of Ornithomya spp. were also collected for species identification. Fly species were identified morphologically and identifications confirmed with DNA barcoding.

Results: We found three species: two louse-flies - Ornithomya chloropus and O. avicularia - and one blow-fly, Protocalliphora azurea. The prevalence of $O$. avicularia was higher in southern latitudes and this species was not encountered beyond $62^{\circ} \mathrm{N}$ whereas $\mathrm{O}$. chloropus and $P$. azurea occurred across the whole range of latitudes. The prevalence of $O$. chloropus further increased with increasing distance from the coast - a pattern not documented before. The three fly species showed no interspecific associations in their prevalence.

Conclusions: Our study revealed relatively high prevalence for all the species (O. chloropus $59 \%$, O. avicularia $20 \%$, P. azurea $32 \%$ ), and an interesting spatial pattern in the prevalence of the two louse fly species. Our sample did not indicate any major range shifts towards the north for the southern species as compared to the information from the past. Morphological identification of $O$. chloropus did not match with the corresponding sequences published in the GenBank and taxonomy of this group calls for further studies.
\end{abstract}

Keywords: Blood parasites, Bird blowflies, Ectoparasite prevalence, Louse flies, Pied flycatcher

\section{Background}

Ectoparasitic louse flies Ornithomya spp. (Diptera, Hippoboscidae) and bird blowflies Protocalliphora spp. (Diptera, Calliphoridae) commonly infest nestling passerines, the former ones sucking blood from nestlings as adults and the latter as in their larval stage [1-3]. Both parasites have been found to inflict negative effects on nestlings, though their effect on nestling mortality is usually weak and causality between parasite numbers and mortality or condition

\footnotetext{
* Correspondence: tapio.eeva@utu.fi

'Department of Biology, University of Turku, Fl-20014 Turku, Finland

Full list of author information is available at the end of the article
}

often remains unclear [4-9]. However, louse flies are vectors of some avian blood protozoans (e.g. Haemoproteus spp. and Trypanosoma spp.), and could have delayed effects on condition or mortality [10-12]. Sub-lethal effects of parasitic bird blowflies include anemia and retardation of growth [5-8, 13]. In Fennoscandia, four species of Ornithomya [14] and five species of Protocalliphora [15] occur but the information on distribution and abundance of these species are incomplete.

Ectoparasites - not only flies but also ticks, mites, and fleas - may also host and transmit zoonoses between animal species, and from animals to humans, including 
e.g. migratory birds [16], birds generally $[17,18]$, raccoon dogs [19], and bats [20, 21]. Especially urban areas have been studied in detail, due to the higher risk for human population [22]. Thus, it is important to identify ectoparasites, reveal their geographical distribution, and unveil ecological interactions with their hosts.

We studied the occurrences of Ornithomya and Protocalliphora species in nests of a common avian model species, the pied flycatcher Ficedula hypoleuca Pallas 1764 across a latitudinal gradient between $56^{\circ} \mathrm{N}-70^{\circ} \mathrm{N}$ in Fennoscandia. The relationships between Ornithomya and Protocalliphora prevalence and breeding success of $F$. hypoleuca, as well as the dependence of parasite prevalence on some environmental variables (e.g. temperature, biotope and pollution) were explored in an earlier paper [9] and are not dealt with here. We identified the fly species on the basis of morphological characters of their puparia (both genera) and adult specimens (for Ornithomya). Some specimens were further DNA barcoded to confirm the morphological identification. Since both fly genera are favored by increasing summer temperatures [9] we were also interested to find out if some of the southern fly species have spread towards the north during the recent period of warming climate in Fennoscandia [23]. We further tested for the association of prevalence between different fly species in parasitizing $F$. hypoleuca broods, i.e. whether their occurrence in a nest is negatively (e.g. by competition; [24]) or positively (e.g. by host quality) associated.

\section{Methods}

A total of 236 nests of $F$. hypoleuca were collected from 21 locations in summer 2013 and parasites recovered and counted (Table 1 and Fig. 1). Only successful nests, i.e. where at least one nestling finally fledged, were sampled. All nest boxes were emptied before the breeding season. All the nest material (including dust at the bottom) was carefully removed from the wooden nest boxes usually within one week of fledging, stored in plastic bags and frozen until the samples were inspected in a laboratory for the puparia of Ornithomya and Protocalliphora. Adult Ornithomya feed especially on nestlings and deposit one fully-grown larva at time [1]. The larvae immediately pupate, overwinter, and hatch the following season [1]. Larvae of Protocalliphora feed periodically on the blood of nestling birds and pupate in the nest material $[15,25]$. The adults emerge some weeks later, overwinter, and lay their eggs following season after nestlings hatch $[3,15]$.

The puparia of Ornithomya were sorted out in two groups based on their morphological characters (size and surface structure) by using stereo microscope. Ten puparia of each type were further used for non-destructive DNA extraction and sequencing [26] and successful PCR products were purified and subsequently sequenced [27]. Whole specimens were incubated $24 \mathrm{~h}$, then the puparia were removed and DNA was purified using either NucleoSpin ${ }^{\circ}$ Tissue XS (small samples) or NucleoSpin ${ }^{\circ}$ Tissue (all other samples) Kit (product numbers 740901 and 740952, respectively; Macherey-Nagel GmbH \& Co. KG, Düren, Germany) from remaining solution. Adult specimens $(n=71)$ of Ornithomya were also collected from nestlings of $F$. hypoleuca, great tit Parus major L. and blue tit Cyanistes caeruleus L. and used for reference material to identify species morphologically and genetically. These came partly from the same nests $(n=19)$ of $F$. hypoleuca where the puparia were sampled. Adult specimens were identified using morphological characters by Antti Haarto (University of Turku). Some specimens $(n=18)$ were then used for DNA extraction and sequencing as described above. Only some of the specimens produced readable DNA sequences, with most of the failed specimens being puparia.

The species identity of all sequenced material was confirmed by downloading all available unique Ornithomya and Protocalliphora COI (cytochrome oxidase subunit I) DNA barcodes from GenBank and BOLD (The Barcode of Life Data Systems), aligning them with our own sequences, calculating distances between each sequence, and finally drawing both neighbor-joining (NJ) and maximum-likelihood (ML) consensus trees using software Geneious and plugins as follows. NJ tree was built with built-in Geneious tree builder with default settings except resampling was carried out with 100 bootstrapping replicates [28]. ML tree was built with PhyML plugin with default settings except for resampling with 100 bootstrap replicates [29].

We concentrate here in analyzing the spatial variation in prevalence because the different parameters showed relatively strong positive correlations $\left(r_{s}\right.$ between 0.50 0.98 in most cases). Furthermore, the number of parasites per nest is likely to be influenced by several environmental factors (e.g. temperature, biotope, brood size, host population density), as well as handling of nestlings [30], which were not controlled for in our study. Geographical trends in prevalence were analyzed for each species with generalized linear mixed model (GLMM; [31]) where occurrence ( 1 = found; 0 = not found) of a species was used as a binary response variable and latitude, longitude and logarithmic (base 10) distance from the coast were used as explanatory variables. Distance from the coast was added in the model as ad hoc variable after noticing in the field that in and close to the archipelago at SW Finland the relative proportions of two Ornithomya species were different than in the inland. Location was used in the models as a random effect to control for spatial independence of the observations. Degrees of freedom were calculated with Kenward-Roger method. The level of significance was set 
Table 1 Sample locations, their distance from the coast and collection dates for Ornithomya chloropus, O. avicularia and Protocalliphora azurea in F. hypoleuca nests in summer 2013 ( $N=$ no. of nests in sample, $P=$ prevalence [\% nests infested], $(n)=$ no. of infested nests, I = intensity [mean number of puparia per infested nest])

\begin{tabular}{|c|c|c|c|c|c|c|c|c|c|c|c|c|}
\hline \multirow[b]{2}{*}{ N.o. } & \multirow[b]{2}{*}{ Location } & \multirow[b]{2}{*}{ Lat ( $\left.{ }^{\circ} \mathrm{N}\right)$} & \multirow[b]{2}{*}{ Lon $\left({ }^{\circ} \mathrm{E}\right)$} & \multirow[b]{2}{*}{ Dist. to coast $(\mathrm{km})$} & \multirow[b]{2}{*}{ Dates } & \multirow[b]{2}{*}{ N } & \multicolumn{2}{|c|}{ O. chloropus } & \multicolumn{2}{|c|}{ O. avicularia } & \multicolumn{2}{|c|}{ P. azurea } \\
\hline & & & & & & & $\mathrm{P} \%(n)$ & 1 & $\mathrm{P} \%(n)$ & I & $\mathrm{P} \%(n)$ & 1 \\
\hline 1 & Borgholm & 56.70 & 16.55 & 3.32 & 26.-28.6. & 10 & 0 & & $30(3)$ & 1.00 & 0 & . \\
\hline 2 & Raasepori & 60.02 & 23.52 & 1.57 & 28.6.-2.7. & 10 & $20(2)$ & 2.00 & $10(1)$ & 2.00 & $60(6)$ & 6.50 \\
\hline 3 & Houtskär & 60.24 & 21.36 & 0.05 & 10.8 & 3 & 0 & & $33(1)$ & 3.00 & $100(3)$ & 5.67 \\
\hline 4 & Kaidanpää & 60.41 & 21.70 & 0.04 & 2.7 & 10 & 0 & . & $20(2)$ & 2.00 & $40(4)$ & 5.50 \\
\hline 5 & Littoinen & 60.44 & 22.37 & 4.61 & 13.8. & 3 & 0 & . & 0 & . & 0 & . \\
\hline 6 & Ruissalo & 60.44 & 22.17 & 0.36 & 5.7. & 10 & 0 & . & $70(7)$ & 2.29 & $40(4)$ & 6.75 \\
\hline 7 & Lemu & 60.57 & 21.97 & 3.29 & 25.6.-14.7. & 10 & $10(1)$ & 1.00 & $40(4)$ & 1.25 & $60(6)$ & 3.67 \\
\hline 8 & Lemmi & 60.79 & 21.97 & 18.6 & 3.7. & 12 & $75(9)$ & 3.44 & $8(1)$ & 1.00 & $58(7)$ & 3.00 \\
\hline 9 & Vaskijärvi & 60.84 & 22.28 & 33.0 & 26.6.-5.7. & 13 & $38(5)$ & 2.60 & $8(1)$ & 1.00 & $38(5)$ & 5.80 \\
\hline 10 & Karjala & 60.90 & 22.10 & 32.5 & 29.6. & 10 & $80(8)$ & 2.63 & 0 & . & $30(3)$ & 4.67 \\
\hline 11 & Panelia & 61.25 & 22.00 & 21.0 & 8.7. & 10 & $90(9)$ & 3.67 & $20(2)$ & 1.50 & $60(6)$ & 4.00 \\
\hline 12 & Palokangas & 61.27 & 22.11 & 27.1 & 8.7 & 20 & $80(16)$ & 5.00 & $10(2)$ & 1.00 & $20(4)$ & 1.75 \\
\hline 13 & Paloasema & 61.31 & 22.14 & 29.7 & 1.7. & 11 & $54(6)$ & 2.33 & $18(2)$ & 2.00 & 0 & . \\
\hline 14 & Ojala & 61.31 & 22.11 & 28.2 & 1.7 & 11 & $100(11)$ & 2.91 & $36(4)$ & 1.00 & 0 & . \\
\hline 15 & Koivula & 61.31 & 22.11 & 28.0 & 1.7. & 22 & $95(21)$ & 2.76 & $18(4)$ & 1.50 & 0 & . \\
\hline 16 & Kallioaro & 61.36 & 21.94 & 19.6 & 8.7 & 14 & $43(6)$ & 2.50 & 0 & . & $29(4)$ & 9.50 \\
\hline 17 & Kauhava & 63.13 & 23.10 & 40.8 & 1.7.-9.7. & 18 & $83(15)$ & 6.07 & 0 & & $61(11)$ & 9.91 \\
\hline 18 & Umeå & 64.20 & 20.85 & 7.29 & 1.7.-10.7. & 10 & $60(6)$ & 3.67 & 0 & . & $20(2)$ & 4.00 \\
\hline 19 & Sanginjoki & 65.02 & 25.77 & 14.4 & 5.7. & 14 & $86(12)$ & 4.25 & 0 & & $43(6)$ & 5.67 \\
\hline 20 & Kalimenkylä & 65.12 & 25.51 & 6.40 & 2.7 & 9 & $89(8)$ & 3.38 & 0 & . & $11(1)$ & 8.00 \\
\hline 21 & Kevo & 69.76 & 27.01 & 69.0 & 8.7.-23.7. & 6 & $67(4)$ & 2.50 & 0 & & $17(1)$ & 7.00 \\
\hline Total & & & & & & 236 & 59 (139) & 3.62 & $14(34)$ & 1.59 & $32(76)$ & 6.34 \\
\hline
\end{tabular}

at $p<0.05$. Non-significant terms were dropped out from the models one by one, starting from the least significant term. The residuals from all models were further tested for spatial autocorrelation with Moran's I coefficients. These indicated no significant spatial autocorrelation in our data (range for I: -0.0099 to $0.0006 ; p>0.45$ in all). For Ornithomya, the reduced models were also run without the cases (O. chloropus, $n=16$; O. avicularia, $n=3$ ) where some adult flies were collected away from host nests (because this could affect the number of puparia). Since this did not markedly affect the results we report the models with full data.

The associations in occurrence between the two observed Ornithomya species and between Ornithomya and Protocalliphora were tested with $\chi^{2}$ test in a contingency table with frequencies of occurrence $(1=$ found; $0=$ not found). For the analysis testing an association between the Ornithomya species we only included the nests from those study sites $(n=9$; Table 1$)$ where both species were found. This was because testing such associations outside the range of the species would not be meaningful.

\section{Results}

On the basis of morphological identification all adult Ornithomya specimens $(n=71)$ collected from the nests belonged to two species, O. chloropus Bergroth 1901 and $O$. avicularia $\mathrm{L}$. The adult specimens used for genetic identification also formed two clearly separate clusters confirming our identification accuracy. However, the species names assigned for the GenBank sequences for the specimens morphologically identified as $O$. chloropus clustered together with a sequence labeled as $O$. anchineura Speiser 1905 (match 98.3-98.9 \%; a taxon described from North America; GenBank accession number EF531227). However our O. avicularia shared highest identity with the $O$. avicularia sequence in GenBank (match 99.1-100 \%; EF531211 and KF453421; see Additional file 1 for taxonomic tree and Additional file 2 for distance table).

The puparia of Ornithomya were also morphologically identified to form two groups, the larger ones O. avicularia (larger species), and the smaller ones as O. chloropus (smaller species) (Fig. 2). The molecular results confirmed 


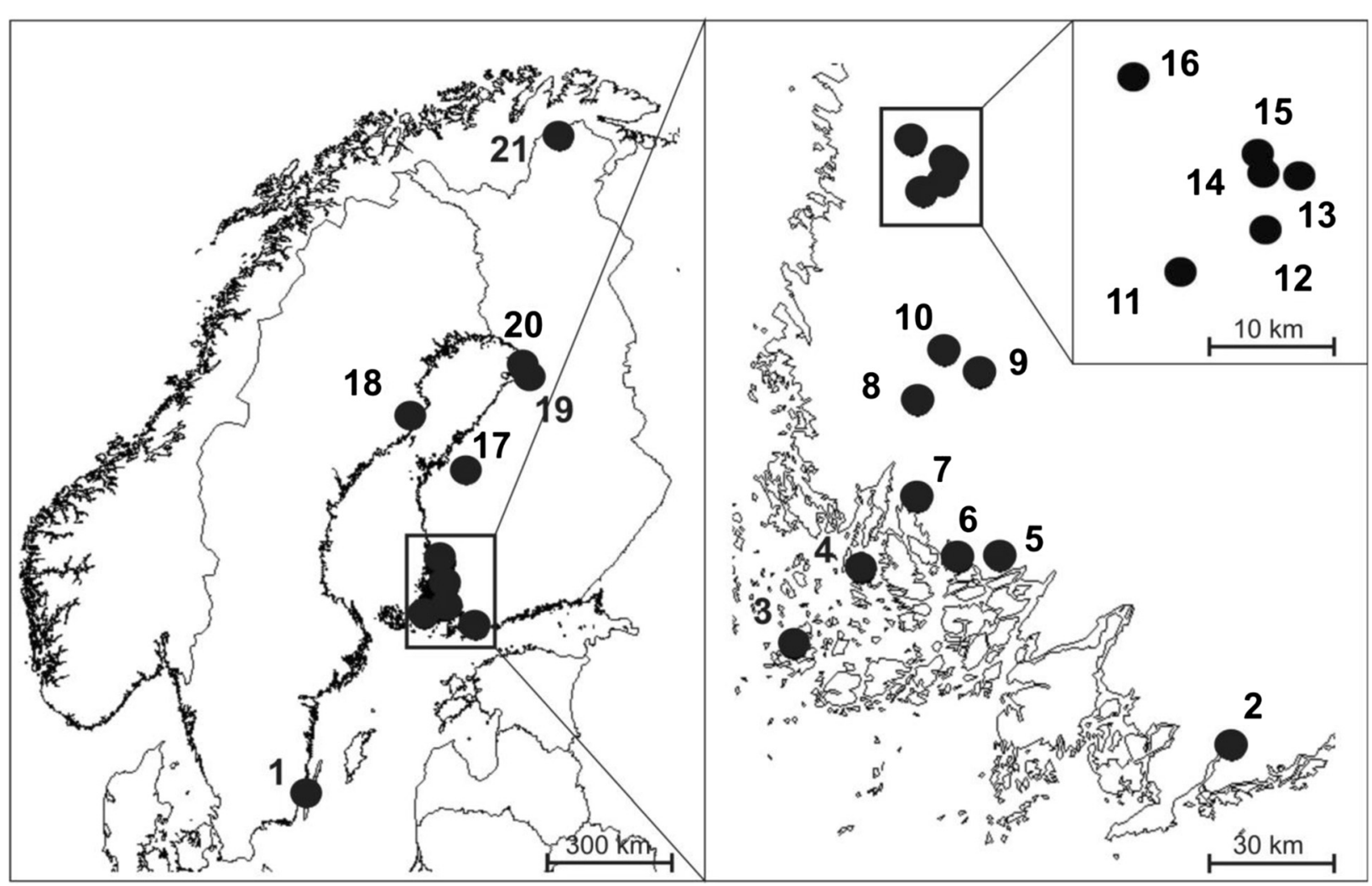

Fig. 1 Maps of Fennoscandia showing 21 locations where the 236 Ficedula hypoleuca nests were collected for this study. More detailed maps are shown for SW Finland, and sites in Satakunta

our identification into two clearly separate species (Additional file 1). However, as in the case of adults, the sequences of puparia clustered with $O$. anchineura and $O$. avicularia. As we currently have no knowledge of the true taxonomical status of the O. anchineura specimen in the GenBank, we retain to our own morphologically identified species names in this study, that is, O. chloropus, and $O$. avicularia. Protocalliphora puparia were determined as $P$. azurea Fallén 1817 (GenBank accsession CQ409352).

Mean prevalence and intensity for all locations are given in the Table 1 and the mean numbers of puparia per nest are shown in the Fig. 3. The prevalence of O. chloropus (mean $59 \%$ ) increased with increasing distance from the coast (Fig. 4a) but showed no significant latitudinal or longitudinal trend (Table 2). Instead, the prevalence of $O$. avicularia (below $61^{\circ}$ the mean was $20 \%$ ) was higher in the south (Fig. 4b) but was not associated with the longitude or distance from the coast (Table 2). Because we had only one data point below $60^{\circ}$ the predicted level for the southernmost location is very inaccurate (Fig. 4b). Latitudinal trend, however, was significant (GLMM, $\left.\mathrm{F}_{1,45.2}=5.1, p=0.030\right)$ even when omitting the southernmost location from the analysis. The prevalence of $P$. azurea (mean $32 \%$ ) showed no significant geographical trend in our sample (Table 2).
Ornithomya chloropus and $O$. avicularia did not show negative or positive association in their occurrence $\left(\chi^{2}=0.006\right.$, $\mathrm{df}=1, p=0.95, n=119$ nests $)$. Neither was there any association in the occurrence of Ornithomya spp. (two species pooled) and P. azurea ( $\chi^{2}=0.72, \mathrm{df}=1, p=0.40, n=236$ nests $)$.

\section{Discussion}

From the nests of F. hypoleuca, we found two species of louse flies, O. chloropus and O. avicularia, and one bird blowfly species, P. azurea. The occurrence of a third common louse fly species in southern Finland, O. fringillina Curtis 1836, generally takes place later in the autumn (peaking in September and October) [14, 32] and was not found in F. hypoleuca nests, though we could not confirm the species for all the puparia collected with barcoding. Nor did we observe the most southern Ornithomya species in Fennoscandia, O. biloba Dufour 1827. Hill et al. [14] explored the Fennoscandian museum specimens of Ornithomya sp. (adults). O. chloropus showed wide distribution from Denmark to northern Norway $\left(70{ }^{\circ} \mathrm{N}\right.$ to $\left.71{ }^{\circ} \mathrm{N}\right)$ whereas the northernmost specimens of $O$. avicularia were found between latitudes $60{ }^{\circ} \mathrm{N}-61^{\circ} \mathrm{N}$ (though occasionally reported farther north; [33]). Our study revealed similar pattern across latitudes, 


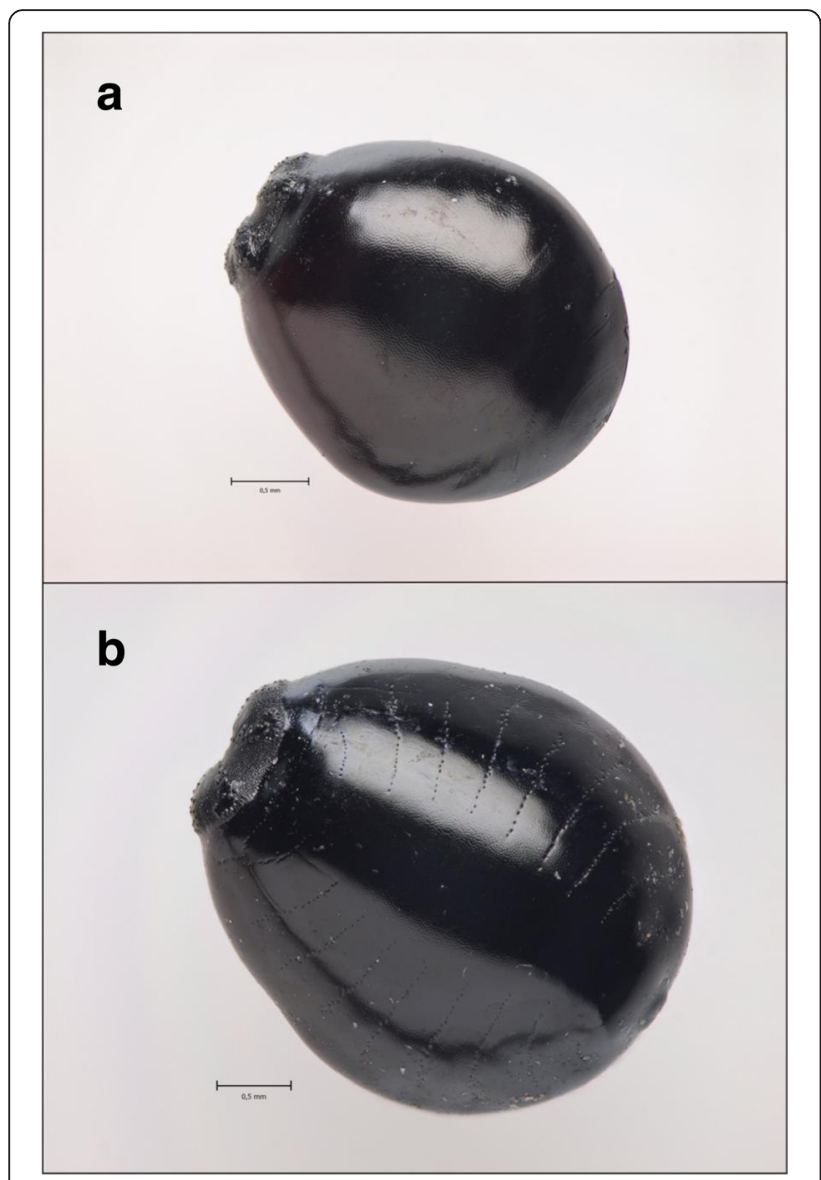

Fig. 2 Puparia of Ornithomya chloropus (a) and O. avicularia (b). Note the larger size and prominent dotted lines of O. avicularia. Scale lines $0.5 \mathrm{~mm}$. Photo: Veikko Rinne

O. chloropus being found from $60.0^{\circ} \mathrm{N}$ to $69.8^{\circ} \mathrm{N}$, while northernmost individuals of $O$. avicularia were found at $61.3^{\circ} \mathrm{N}$. This suggests that the southern species, O. avicularia, has not markedly expanded its range towards north since times before 1964 (time range for the museum samples was not given) despite that climate in Finland has been warming $>2{ }^{\circ} \mathrm{C}$ since 1800's (especially after 1960's and especially at northern latitudes; [23]) and despite the abundance of Ornithomya spp. in F. hypoleuca nests is higher in warm summers [9]. However, due to relatively coarse latitudinal coverage of our study, as well as that of Hill et al. [14], small range shifts would likely be undetected with this comparison.

Both species of Ornithomya are hosted by many bird species $[14,34,35]$ and since their host preferences are not well known the numbers found in the nests of $F$. hypoleuca may not be used as comparable estimates of their total abundance. For example, O. avicularia has been found to prefer relatively large host species (e.g. Turdidae and Corvidae) while O. chloropus accepts larger array of hosts with more variable size [36]. The general abundance of the former species could therefore be underestimated on the basis of F. hypoleuca nest material. In any case, on the basis of numbers and prevalence, $O$. chloropus poses higher parasitic stress on $F$. hypoleuca nestlings than $O$. avicularia, though even their combined intensity would have relatively weak acute effects on nestling survival [9]. In general, Ornithomya prevalence shows considerable annual variation, and is highest in warm summers [9]. In 2013, the weather during the main nestling period of $F$. hypoleuca was relatively warm (mean June temperature $16.5{ }^{\circ} \mathrm{C}$ in SW Finland) and the combined prevalence of the two Ornithomya species in SW Finland was higher than reported in the preceding years 2006-2012 [9]. Therefore, the prevalence levels found in the current study represent favorable conditions and likely differ from those found during colder summers.

We do not know why O. chloropus becomes less prevalent towards the coast, but the reasons could be climatic as the sea has a cooling effect on the coast during the spring [37] and the proximity of sea could delay the phenology of this parasitic fly. For Lipoptena cervi L., a louse-fly ectoparasite of cervids, low summer temperatures were found to prolong the developmental periods and delay the emergence of adult flies [38]. In our study area, also spatial heterogeneity of habitats is likely higher near the coast, forested areas farther from the coast being larger and more uniform. O. chloropus, however, is hosted by wide variety of bird species, including ones in open habitats [35], and is therefore not restricted to occur in forested areas. We found no association in prevalence between the two Ornithomya species and interspecific competition between them is an unlikely explanation for the observed spatial pattern. The observed pattern has not been reported earlier and it calls for further studies.

One successfully DNA barcoded Protocalliphora puparia was identified as $P$. azurea. On the basis of the similar morphological appearance of the rest of the puparia in our sample, we assumed all were the same species, though there still remains a possibility that some other species are included in our sample. However, in a sample of puparia grown to adulthood $(n=107$ individuals), collected at or near the locations 10-16 (Fig. 1) in the beginning of the 1990s, no other species were found [39]. Protocalliphora azurea is widely distributed in the Palearctic region and is hosted by multiple bird species [15]. We found no significant geographical trends in the numbers of Protocalliphora puparia. Sites 13-15 are affected by air pollution from a copper smelter and scanty field layer vegetation may explain why no puparia were found at these locations since adult flies feed on flowers [25] and favor locations with luxuriant field layer vegetation [39]. A recent study from SW Finland found no 

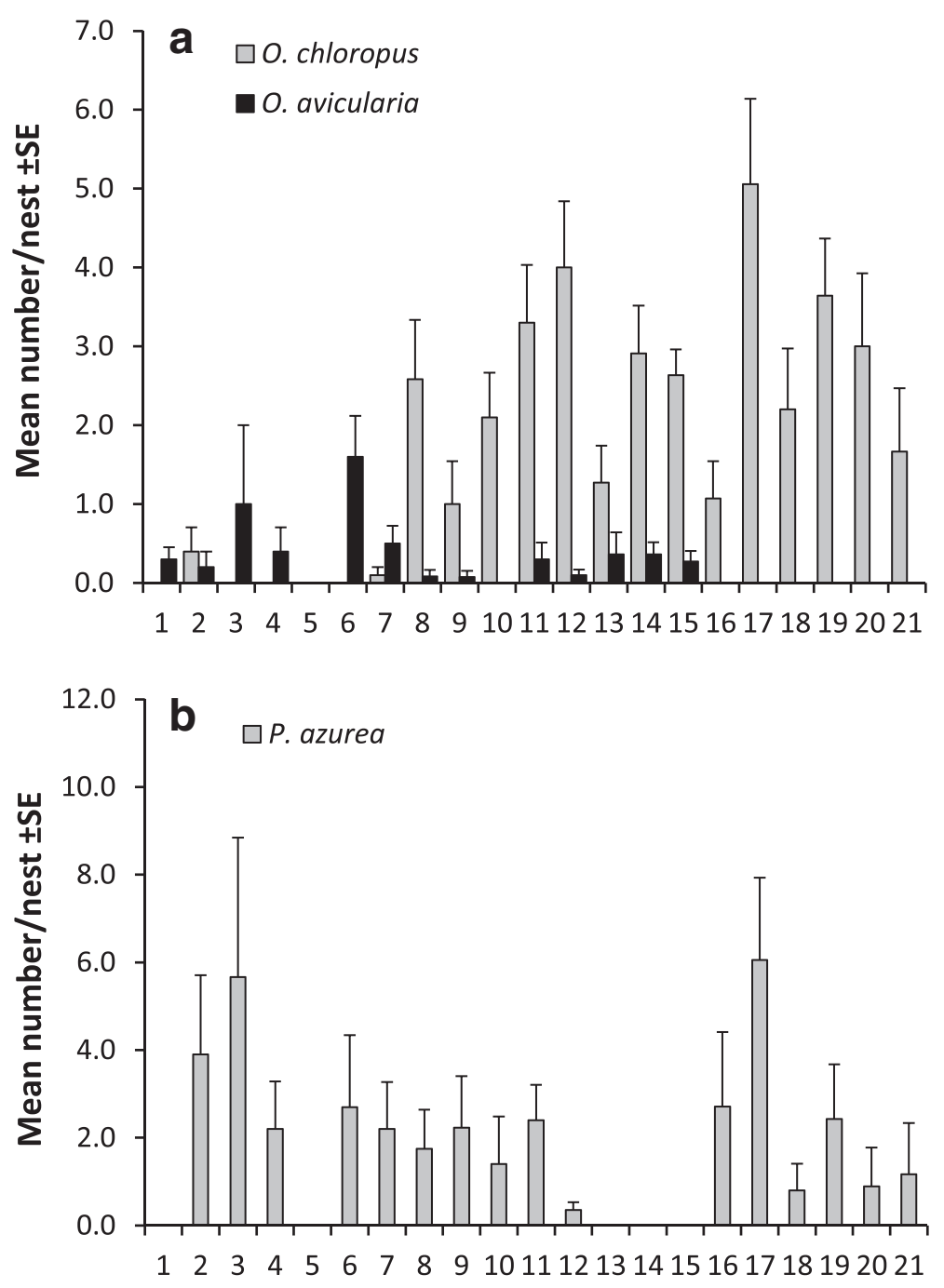

Site

Fig. 3 Means and standard errors for the numbers of (a) Ornithomya species and (b) Protocalliphora azurea puparia in the nests of $F$. hypoleuca at sampling sites (sorted from south to north; see Fig. 1). Sample sizes are shown in Table 1

effects of Protocalliphora on F. hypoleuca nestling mortality at corresponding levels of intensity as in the current study [9], but high intensities have been shown to increase nestling mortality in the tree sparrow, Passer montanus L. [40].

A peculiar phenomenon coming up in our results was the taxonomical (or only nomenclatural) confusion of Ornithomya species. Based on literature, traditional morphological identification of the smaller bird louse species in our study is $O$. chloropus, and the larger species $O$. avicularia. However, our own O. chloropus sequences matched most closely with the only $O$. anchineura in the public databases (EF531227), published by Petersen et al. [41]. Furthermore, the only two available O. chloropus sequences in the public databases (EF531213, KF453423) formed a separate cluster, matching $100 \%$ to each other.
Being beyond the scope of the current study, we leave this question open and call for future work to properly address this problem.

\section{Conclusions}

Our study revealed relatively high prevalence for all the fly species in nests of $F$. hypoleuca and interesting spatial patterns in prevalence of the two louse flies. Our sample, however, did not indicate any major northward range shifts for the southern species as a consequence of warmer climate as compared to the information from the past. Taxonomy, differences in spatial prevalence of Ornithomya species and their roles in transmitting blood parasites call for further studies. For example, it would be interesting to compare blood parasite prevalence between the Ornithomya species. If the two Ornithomya 

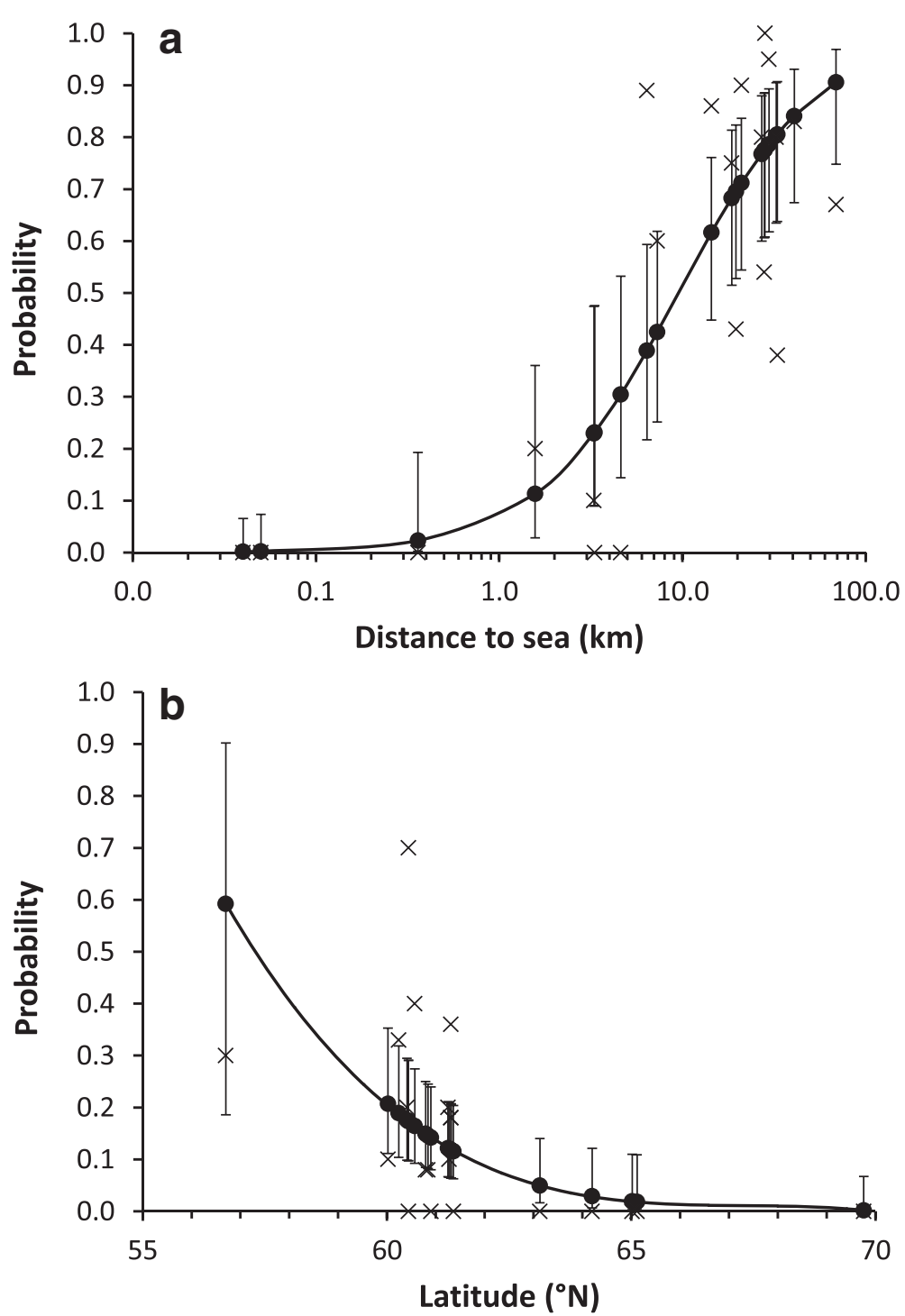

Fig. 4 Prevalence $(X)$ in F. hypoleuca nests of (a) O. chloropus relative to distance from the coast, and of (b) O. avicularia relative to latitude. Predicted values $(\bullet)$ and $95 \%$ confidence limits are produced by reduced models shown in Table 2. Sample sizes are shown in Table 1

Table 2 Generalized linear mixed models $\left(G L M M^{a}\right)$ for explaining geographical trends in prevalence of puparia of three parasitic fly species in the nests $(n=236)$ of Ficedula hypoleuca

\begin{tabular}{|c|c|c|c|c|c|c|c|c|c|}
\hline & \multicolumn{3}{|l|}{ O. chloropus } & \multicolumn{3}{|l|}{ O. avicularia } & \multicolumn{3}{|l|}{ P. azurea } \\
\hline & $\overline{\beta \pm S E}$ & $\mathrm{~F}_{\mathrm{df}}$ & $P$ & $\overline{\beta \pm S E}$ & $\mathrm{~F}_{\mathrm{df}}$ & $P$ & $\overline{\beta \pm S E}$ & $\mathrm{~F}_{\mathrm{df}}$ & $P$ \\
\hline Intercept & $-2.57 \pm 0.85$ & & & $29.7 \pm 12.2$ & & & $-0.422 \pm 0.44$ & & \\
\hline Latitude $\left({ }^{\circ} \mathrm{N}\right)$ & $-0.0153 \pm 0.23$ & $0.00_{1,12.0}$ & 0.95 & $-0.517 \pm 0.20$ & $6.61_{1,23.8}$ & 0.017 & $-0.167 \pm 0.24$ & $0.501,15.0$ & 0.49 \\
\hline Longitude $\left({ }^{\circ} \mathrm{E}\right)$ & $0.237 \pm 0.18$ & $1.81_{1,20.3}$ & 0.19 & $0.190 \pm 0.35$ & $0.30_{1,22.9}$ & 0.59 & $0.200 \pm 0.17$ & $1.331,18.9$ & 0.26 \\
\hline Log distance from the coast $(\mathrm{km})$ & $2.63 \pm 0.67$ & $15.2_{1,26.6}$ & 0.0006 & $-0.432 \pm 0.34$ & $1.631,15.2$ & 0.22 & $-0.558 \pm 0.35$ & $2.48_{1,16.1}$ & 0.13 \\
\hline
\end{tabular}

Reduced models are shown in bold

${ }^{a}$ GLMM with binary error distribution, logit link function, and location $(n=21)$ as a random factor 
species would differ in their rates of transmitting blood parasites, spatial gradient in their relative numbers could produce corresponding spatial gradients in blood parasite prevalence. Such spatial gradients in blood parasite prevalence have been previously reported (e.g. in Parids) relative to the distance to water bodies [42].

\section{Additional files}

Additional file 1: Molecular analysis of puparia and adult bird louse flies. Species and abundance of louse flies (Ornithomya spp.) and blowflies (Protocalliphora spp.) in nests of the pied flycatcher. (DOCX $46 \mathrm{~kb}$ )

Additional file 2: Genetic distances between individual sequences. (XLSX $18 \mathrm{~kb})$

\section{Competing interests}

The authors declare that they have no competing interests.

\section{Authors' contributions}

TE conceived and designed the project and analyzed the data. EJV did the DNA barcoding. All the authors participated in the collection of data and drafted the manuscript. All authors read and approved the final manuscript

\section{Acknowledgements}

Tuija Koivisto and biology students in the University of Turku are warmly acknowledged for sorting out the nest material. Antti Haarto (Zoological Museum, University of Turku) kindly identified the adult louse fly specimens. Veikko Rinne (Zoological Museum, University of Turku) took the photographs of louse fly cocoons. Jorma Nurmi and Miia Rainio took part in the collection of nest material. We thank Rudolf Meier and two anonymous referees for their suggestions to improve our manuscript. This study was financed by the Academy of Finland (TE: project 265859), Turku University Foundation, Ella and Georg Ehrnrooth foundation, and Emil Aaltonen Foundation (EJV).

\section{Author details}

${ }^{1}$ Department of Biology, University of Turku, Fl-20014 Turku, Finland. ${ }^{2}$ Kevo Subarctic Research Institute, University of Turku, Fl-20014 Turku, Finland. ${ }^{3}$ Department of Ecology and Environmental Science, Umeå University, Umeå, Sweden. ${ }^{4}$ Varnankatu 2 D, Fl-20320 Turku, Finland. ${ }^{5}$ Department of Biology, University of Oulu, Fl-90014 Oulu, Finland. ${ }^{6}$ Finnish Natural History Museum, Zoology Unit, University of Helsinki, Fl-00014 Helsinki, Finland. 'Department of Agricultural Sciences, Spatial Foodweb Ecology Group, University of Helsinki, Fl-00014 Helsinki, Finland.

Received: 8 October 2015 Accepted: 11 December 2015

Published online: 21 December 2015

\section{References}

1. Corbet GB. The life-history and host-relations of a Hippoboscid fly Ornithomyia fringillina Curtis. J Anim Ecol. 1956;25:403-20.

2. Gold CS, Dahlsten DL. Effects of parasitic flies (Protocalliphora spp.) on nestling mountain and chestnut-backed chickadees. Wilson Bull. 1983;95:560-72.

3. Hori K, Iwasa M, Ogawa R. Biology of two species of the Protocalliphora (Diptera: calliphoridae) in Tokachi, Hokkaido, Japan: feeding behaviour of larvae, larval and pupal durations, voltinism and host specificity. Appl Entomol Zool. 1990;25:475-82.

4. Sabrosky CW, Bennett GF, Whitworth TL. Bird blow flies (Protocalliphora) in North America (Diptera: Calliphoridae), with notes on the Palearctic species. Washington, DC: Smithsonian Institution Press; 1989.

5. Whitworth TL, Bennett GF. Pathogenicity of larval Protocalliphora (Diptera: Calliphoridae) parasitizing nestling birds. Can J Zool. 1992;70:2184-91.

6. Simon A, Thomas D, Blondel J, Perret P, Lambrechts MM. Physiological ecology of Mediterranean blue tits (Parus caeruleus L.): effects of ectoparasites (Protocalliphora spp.) and food abundance on metabolic capacity of nestlings. Physiol Biochem Zool. 2004;77:492-501.
7. Hannam K. Ectoparasitic blow flies (Protocalliphora sp.) and nestling Eastern Bluebirds (Sialia sialis): direct effects and compensatory strategies. Can J Zool. 2006;84:921-30.

8. Gentes ML, Whitworth TL, Waldner C, Fenton H, Smits JE. Tree swallows (Tachycineta bicolor) nesting on wetlands impacted by oil sands mining are highly parasitized by the bird blow fly Protocalliphora spp. J Wildl Dis. 2007; 43:167-78.

9. Eeva T, Klemola T. Variation in prevalence and intensity of two avian ectoparasites in a polluted area. Parasitology. 2013;140:1384-93.

10. Baker JR. A review of the role played by the Hippoboscidae (Diptera) as vectors of endoparasites. 1967. p. 412-418.

11. Martinez-de la Puente J, Merino S, Tomás G, Moreno J, Morales J, Lobato E, et al. The blood parasite Haemoproteus reduces survival in a wild bird: a medication experiment. Biol Lett. 2010;6:663-5.

12. Santiago-Alarcon D, Palinauskas V, Schaefer HM. Diptera vectors of avian Haemosporidian parasites: untangling parasite life cycles and their taxonomy. Biol Rev. 2012;87:928-64.

13. Banbura J, Perret P, Blondel J, Thomas DW, Cartan-Son M, Lambrechts MM. Effects of Protocalliphora parasites on nestling food composition in Corsican Blue Tits Parus caeruleus: consequences for nestling performance. Acta Ornithologica. 2004:39:93-103.

14. Hill DS, Hackman W, Lyneborg L. The genus Ornithomya (Diptera: Hippoboscidae) in Fennoscandia, Denmark and Iceland. Notulae Entomologicae. 1964;44:33-52.

15. Rognes K. Blowflies (Diptera, Calliphoridae) of Fennoscandia and Denmark. ed 24, Leiden, New York, KØbenhavn, Köln, E. J. Brill/Scandinavian Science Press Ltd. 1991

16. Georgopoulou I, Tsiouris $\mathrm{V}$. The potential role of migratory birds in the transmission of zoonoses. Vet Ital. 2008:44:671-7.

17. Haag-Wackernagel D, Bircher AJ. Ectoparasites from feral pigeons affecting humans. Dermatology. 2010;220:82-92.

18. Hamer S, Lehrer E, Magle S. Wild birds as sentinels for multiple zoonotic pathogens along an urban to rural gradient in greater Chicago, Illinois. Zoonoses and Public Health. 2012;59:355-64.

19. Sutor A, Schwarz S, Conraths FJ. The biological potential of the raccoon dog (Nyctereutes procyonoides, Gray 1834) as an invasive species in Europe - new risks for disease spread? Acta Theriol. 2014;59:49-59.

20. Hornok S, Kovacs R, Meli M, Goenczi E, Hofmann-Lehmann R, Kontschan J, et al. First detection of bartonellae in a broad range of bat ectoparasites. Vet Microbiol. 2012;159:541-3.

21. Veikkolainen V, Vesterinen EJ, Lilley TM, Pulliainen AT. Bats as reservoir hosts of human bacterial pathogen, Bartonella mayotimonensis. Emerg Infect Dis. 2014;20:960-7.

22. Delgado CA, French K. Parasite-bird interactions in urban areas: Current evidence and emerging questions. Landsc Urban Plan. 2012;105:5-14.

23. Mikkonen S, Laine M, Mäkelä HM, Gregow H, Tuomenvirta H, Lahtinen M, et al. Trends in the average temperature in Finland, 1847-2013. Stoch Env Res Risk A. 2015:29:1521-9.

24. van den Broek E, van Eck HM. Species of Ornithomyia (Diptera: Hippoboscidae) from the Dutch North Sea island of Vlieland. Trans $R$ Entomol Soc London. 2015;115:391-407.

25. Bennett GF, Whitworth TL. Studies on the life history of some species of Protocalliphora (Diptera: Calliphoridae). Can J Zool. 1991;69:2048-58.

26. Sorvari J, Härkonen SK, Vesterinen EJ. First record of an indoor pest sawtoothed grain beetle Oryzaephilus surinamensis (Coleoptera: Silvanidae) from wild outdoor wood ant nest. Entomologica Fennica. 2012;23:69-71.

27. Pilipenko VE, Salmela J, Vesterinen EJ. Description and DNA barcoding of Tipula (Pterelachisus) recondita sp n. from the Palaearctic region (Diptera, Tipulidae). Zookeys. 2012;192:51-65.

28. Kearse M, Moir R, Wilson A, Stones-Havas S, Cheung M, Sturrock S, et al. Geneious basic: an integrated and extendable desktop software platform for the organization and analysis of sequence data. Bioinformatics. 2012;28:1647-9.

29. Guindon S, Gascuel O. A simple, fast, and accurate algorithm to estimate large phylogenies by maximum likelihood. Syst Biol. 2003;52:696-704.

30. Vastveit HR. Spatial and temporal variation in hippoboscid parasitism by Ornithomya chloropus on house sparrows (Passer domesticus) and its effect on survival. M Sc thesis 2013; Norvegian University of Science and Technology. 35 pages.

31. SAS Institute Inc. Base SAS 9.4 procedures guide: statistical procedures. Cary, NC: SAS Institute Inc.; 2013

32. Sorjonen J. Occurrence of three species of Ornithomya Diptera, Hippoboscidae on birds in two areas of southern Finland. Ann Zool Fenn. 1971:8:442-5. 
33. Helle P, Hyytinen L, Itämies J. Observations made in 1974 on Diptera, Hippoboscidae, at Kaarlela, Tankar, Finnish W. coast. Luonnon Tutkija. 1977:81:57-8.

34. Maa TC. A revised checklist and concise host index of hippoboscidae (Diptera). Pacific Insects Monograps (Honolulu: Bishop Museum, Honolulu, Hawaii). 1969:20:261-99.

35. Hutson AM. Keds, flat-flies and bat-flies. Hippoboscidae and Nycterbiidae. London, Royal Entomological Society of London: Diptera; 1984.

36. Helle P, Hyytinen L, Itämies J. Records of bird-flies (Diptera, Hippoboscidae) from northern Finland. Ann Zool Fenn. 1977;14:232-4.

37. Kitayama H, Katayama T, Hayashi T, Tsutsumi J, Ishii A. Statistical analysis of the sea land breeze and its effect on the air-temperature in summer. J Wind Eng Ind Aerodyn. 1991;38:93-9.

38. Härkönen L, Härkönen S, Kaitala A, Kaunisto S, Kortet R, Laaksonen S, et al. Predicting range expansion of an ectoparasite - the effect of spring and summer temperatures on deer ked Lipoptena cervi (Diptera: Hippoboscidae) performance along a latitudinal gradient. Ecography. 2010;33:906-12.

39. Eeva T, Lehikoinen E, Nurmi J. Effects of ectoparasites on breeding success of great tits (Parus major) and pied flycatchers (Ficedula hypoleuca) in an air pollution gradient. Can J Zool. 1994;72:624-35.

40. Puchala P. Detrimental effects of larval blow files (Protocalliphora azurea) on nestlings and breeding success of Tree Sparrows (Passer montanus). Can J Zool. 2004;82:1285-90.

41. Petersen FT, Meier R, Kutty SN, Wiegmann BM. The phylogeny and evolution of host choice in the Hippoboscoidea (Diptera) as reconstructed using four molecular markers. Mol Phylogenet Evol. 2007;45:111-22.

42. Krama T, Krams R, Cirule D, Moore FR, Rantala MJ, Krams IA. Intensity of haemosporidian infection of parids positively correlates with proximity to water bodies, but negatively with host survival. J Ornithol. 2015;156:1075-84.

\section{Submit your next manuscript to BioMed Central and we will help you at every step:}

- We accept pre-submission inquiries

- Our selector tool helps you to find the most relevant journal

- We provide round the clock customer support

- Convenient online submission

- Thorough peer review

- Inclusion in PubMed and all major indexing services

- Maximum visibility for your research

Submit your manuscript at www.biomedcentral.com/submit

C Biomed Central 